BJHS: Themes 3: 147-165, 2018. C British Society for the History of Science 2018. This is an Open Access article, distributed under the terms of the Creative Commons Attribution licence (http://creativecommons.org/licenses/by/4.0/), which permits unrestricted re-use, distribution, and reproduction in any medium, provided the original work is properly cited.

doi:10.1017/bjt.2018.2 First published online 12 April 2018

\title{
Observation versus experimentation in natural- history teaching in Portuguese secondary schools: educational laws from 1836 to 1933
}

\author{
INÊS GOMES*
}

\begin{abstract}
The idea that a public and secular institution was needed to prepare citizens for higher education proliferated throughout Europe during the nineteenth century. However, because of local political, economic and social contexts the underlying model of what is now meant by secondary education has developed differently in each country. This essay provides a historical account of the development of secondary education in Portugal, in what concerns the study of nature (zoology, botany, geology and mineralogy) in liceus, during the nineteenth and early twentieth centuries. In particular, the importance given to specimens and collections will be emphasized. The emergence of laboratory-based teaching never replaced traditional approaches centred on observation of specimens. By focusing on the Portuguese case, this article aims ultimately to contribute to a broader understanding of the secondary-educational model implemented throughout Europe in the nineteenth century.
\end{abstract}

The idea that public and secular institutions were needed to prepare citizens for higher education proliferated throughout Europe during the nineteenth century, following French and German examples. ${ }^{1}$ Countries observed each other's educational policies, taking them into account when reforming their own systems. ${ }^{2}$ However, because of local political, economic and social contexts the underlying model of what is now meant by secondary education developed differently in each country.

* Centro Interuniversitário de História das Ciências e da Tecnologia (CIUHCT), Departamento de História e Filosofia das Ciências da Faculdade de Ciências da Universidade de Lisboa, Edifício C4, 3. piso, gabinete 09, Campo Grande, 1749-016 Lisboa, Portugal. Email: gomes.ida@gmail.com.

This work was funded by Fundação para a Ciência e a Tecnologia (uid/his/00286/2013). I also acknowledge the fellowships awarded (sfrh/bd/ 47653 /2008). I would like to thank Isabel Zilhão, who read the manuscript and made many comments and suggestions. This paper also benefited greatly from the discussion with Marta Lourenço, Teresa Salomé Mota, Melanie Keene and Leoncio López-Ocón Cabrera.

1 See Andy Green, Education and State Formation: The Rise of Education Systems in England, France and the USA, London: Macmillan, 2004; Robert Anderson, 'The idea of the secondary school in nineteenth-century Europe', Paedagogica Historica (2004) 40, pp. 93-106.

2 See, for example, Josep Simon, 'The Franco-British communication and appropriation of Ganot's Physique (1851-1881)', in Josep Simon and Néstor Herran (eds.), Beyond Borders: Fresh Perspectives in History of Science, Newcastle upon Tyne: Cambridge Scholars Publishing, 2008, pp. 141-168. The importance of crossnational and comparative studies of science, technology and medicine has been explored in two special issues of History of Science (2012) 50, pp. 251-375, and Science \& Education (2013) 22, pp. 763-920. 
Portugal was no exception to this scenario and, in fact, the foundation of its secondary schools embodied 'the idea of the secondary school in nineteenth-century Europe' ${ }^{3}$ In 1836, a decree on education became a turning point in the creation of a modern educational system in Portugal. ${ }^{4}$ Liceus, the counterparts of the French lycées or the German Gymnasien, were built in each capital district over the following decades. ${ }^{5}$ As far as science is concerned, this first decree clearly reflected the growing interest in science education by the official authorities. Science was central to the endeavour of modernizing the country and developing the nation. Consequently, the effort to institute science subjects in the secondary-school curriculum was simultaneous with the establishment of a national secondary-school network.

This essay provides a historical account of the development of secondary education in Portugal, in what concerns the study of nature (zoology, botany, geology and mineralogy - traditionally called natural history ${ }^{6}$ ) in liceus, during the nineteenth and twentieth centuries, paying particular attention to the period between 1836 and 1933, an epoch that encompassed a constitutional monarchy (1820-1910), a republic (1910-1926) and a dictatorship (1926-1933). ${ }^{7}$ This period coincided, on the one hand, with the proliferation of science teaching in secondary education at the European level, and, on the other hand, with the international pedagogical renewal movements of the first thirty years of the twentieth century. The focus of this paper is on practical natural-history classes based on hands-on exercises, as opposed to theoretical classes based on explanations and textbooks. In particular, I aim to put forward a more comprehensive explanation of the importance and role given to specimens and collections in educational laws, as opposed to the importance given to laboratory-based science teaching. In other words, I want to underline how two different approaches to science teaching, observation and experimentation were appreciated through time.

In this context, a few concepts should be clarified. Natural history is the study of zoology, botany, geology and mineralogy, taking into account, mainly, methodologies centred on observation as opposed to experimentation. Therefore the terms 'historical-naturalistic character' and 'laboratory-based science teaching', as used here, mean, precisely, a focus on observational methods versus a focus on experimental and inquiry-based methods.

3 Anderson, op. cit. (1). On the Portuguese educational system of the nineteenth century see Luís de Albuquerque, Estudos de História, 6 vols., Coimbra: Universidade de Coimbra, 1974-1978, vol. 6; Rómulo de Carvalho, História do ensino em Portugal desde a fundação da nacionalidade até ao fim do regime de Salazar-Caetano, Lisbon: Fundação Calouste Gulbenkian, 1987; Maria Cândida Proença (ed.), O Sistema de Ensino em Portugal, Séculos XIX-XX, Lisbon: Edições Colibri, 1998; Rogério Fernandes, O Pensamento Pedagógico em Portugal, Lisbon: Instituto de Cultura e Língua Portuguesa, 1992.

4 Decreto de 17 de Novembro de 1836, Diário do Governo n. ${ }^{\circ}$ 275/1836.

5 The 1836 decree determined the construction of secondary schools in each capital district, which meant eighteen secondary schools on the mainland. In 1950 its number increased to thirty-five.

6 Zoology, botany, geology and mineralogy were usually taught under the same subject heading, the designation of which - natural history, natural sciences, biology and so on, for example - has changed over the years.

7 The 28 May 1926 coup d'état established a military dictatorship. In 1933 a new Constitution entered into force, which institutionalized the Estado Novo (New State), which ruled until the revolution of 25 April 1974. 
The concepts of 'museum' and 'collection' also need clarification. The word 'museum' did not have the same meaning throughout the nineteenth and twentieth centuries, nor were what secondary schools specifically designated 'school museums' the same as in the present day. A 'museum' or 'cabinet' at the time would be what we call today a 'collection', specifically a 'scientific collection' as defined by the Portuguese Research Infrastructure of Scientific Collections (PRISC):

Scientific Collections are organised assemblages of selected material evidence of the natural environment or scientific human activity, accompanied by the necessary associated information that makes them sources for science communication and for research and teaching in a wide range of cross-disciplinary fields. ${ }^{8}$

The designation of a school museum can thus be applied to collections of any nature, organized by the teacher, as a teaching aid.

This paper accepts that, as others studies have shown, the development and role of teaching collections have been influenced by educational laws. ${ }^{9}$ It is not denied here that there are differences between the 'real school' - meaning the teaching practice that actually occurs in the classroom - and the 'desired school' - meaning the teaching practice that is prescribed in educational laws. Alongside written documents, objects and collections which embody important features of the 'real' scientific and pedagogical practice have become important sources to be taken into account. ${ }^{10}$ However, the fact remains that the 'real school' is a function of the 'desired school'. ${ }^{11}$ Educational laws are therefore crucial to an attempt to understand the growth, use and role of teaching collections. In the face of the scarcity of historiography about material-culture collections in secondary education in Southern Europe, in particular in Portugal, this paper aims to be a point of departure to further research on how natural history was taught in Portugal and its interplay with teaching collections. Although the analysis is centred on educational laws, other important sources include teachers' reports, school yearbooks, journal articles, inventories and correspondence between institutions, used freely here for their useful insights into the history of everyday educational reality.

The article takes a chronological approach. First, a brief presentation of the historical context in which science was introduced in the secondary-school curricula will be

8 PRISC, Portuguese Research Infrastructure of Scientific Collections, at www.prisc.pt, accessed 30 September 2014, original emphasis.

9 For example, Josep Simon, José Ramón Bertomeu-Sánchez and Antonio García-Belmar, 'Nineteenthcentury scientific instruments in Spanish secondary schools', in Marta C. Lourenço and Ana Carneiro (eds.), The Laboratorio Chimico Ouverture: Spaces and Collections in the History of Science, Lisbon, Lisbon: MCUL, 2009, pp. 167-184; Josep Simon and Mar Cuenca-Lorente, 'Science education and the material culture of the nineteenth-century classroom: physics and chemistry in Spanish secondary schools', Science \& Education (2012) 21, pp. 227-244.

10 The importance of studies using objects as primary sources for research in the history of science education has been increasing during the last decade. See, for example, Peter Heering and Roland Wittje (eds.), Learning by Doing: Experiments and Instruments in the History of Science Teaching, Stuttgart: Franz Steiner Verlag, 2011; or the thematic issue of Science Education (2012) 21, pp. 151-288, The History of Experimental Science Teaching.

11 Marta Macedo, Projectar e construir a nação: Engenheiros e território em Portugal no século XIX, Lisbon: ICS, 2012, p. 75. 
outlined. Second, Portuguese educational laws will be explored, comparing the ways in which they addressed different teaching approaches (such as observation and experimentation). Finally, I will address some hypotheses about the reasons why observation, rather than experimentation, was the method of study most widely advocated.

It should be noted that a detailed analysis of every educational reform will not be presented here. The main purpose of this research has been to identify some examples that allow general trends and patterns regarding natural-history teaching collections to be found and described. Therefore, an emphasis will be given to educational laws issued (1) between 1836 and 1894, a period when science faced serious difficulties in its establishment in secondary schools; (2) in 1894/1895, once these laws were considered 'the most important fact[s]' in the history of Portuguese liceus; (3) in 1914, when a new approach to science teaching was legislated; and (4) in 1929, when practical science teaching was officially regulated. Particular emphasis will be placed on the contextualization and description of the 1836 law which created secondary schools, since this law broke with the status quo, building a completely different system of secondary education. On the other hand, the importance given to specimens and collections in educational laws did not disappear from Portuguese legislation after 1933. Therefore educational laws issued after the creation of the Estado Novo will also be discussed. By addressing the Portuguese case, this article aims ultimately at contributing to a broader understanding of the secondary educational model implemented throughout Europe in the nineteenth century. ${ }^{12}$

\section{A brief historical context}

In 1836, Passos Manuel (alias Manuel da Silva Passos, 1801-1862, Minister of the Kingdom) initiated a concerted effort to reform public education. The Liberal Revolution, in 1820, influenced by the cultural and ideological values that characterized the French revolutionary movement, put education on the agenda. The state of public education and its importance were, at the time, a theme much debated in parliament (the Câmara dos Senhores Deputados). ${ }^{13}$ The issue was imperative as it was a key instrument in building a nation based on the values of freedom, secularity and citizenship. ${ }^{14}$ However, the political situation after the Revolution, when a civil war spread throughout the country, ${ }^{15}$ was not particularly favourable to educational reforms, which only

12 The history of science has privileged a set of countries, namely France, Great Britain and Germany. However, as pointed by Carolino, attention to the countries of the European periphery in the nineteenth and twentieth centuries challenges their usual perception as passive receivers and sees them instead as interesting sites of active engagement, appropriating different models and creating their own educational systems. Luís Carolino, 'The making of an academic tradition: the foundation of the Lisbon Polytechnic School and the development of higher technical education in Portugal (1779-1837)', Paedagogica Historica (2012) 28, pp. 391-410, 410.

13 Luís Reis Torgal and Isabel Nobre Vargues, A revolução de 1820 e a instrução pública, Porto: Paisagem Editora, 1984, pp. 39-40, 62; Albuquerque, op. cit. (3), p. 65.

14 Torgal and Vargues, op. cit. (13), pp. 9-10. See also Luís Reis Torgal, 'A instrução pública', in José Mattoso (ed.), História de Portugal, 9 vols., Lisbon: Círculo de Leitores, 1993, vol. 5, pp. 609-651.

15 Between 1828 and 1834. 
occurred, as mentioned, in $1836 .{ }^{16}$ Primary and secondary education were, then, the main targets. In Portugal, just as in other European countries, the construction of nation states walked alongside science and technology, the institutional base of which went beyond the borders of higher education. For instance, in France, besides the école polytechnique, the école normale supérieure, which prepared secondary-school teachers, had its great development from $1808 .{ }^{17}$

Alongside the inspiring role of European secondary schools, Portuguese local conditions and pre-existent academic traditions were decisive in the emergence of a secondary educational system that gave science an important role. In the first half of the eighteenth century, 'science' became a relevant issue. For instance, interest in gathering naturalia increased among collectors. ${ }^{18}$ Portuguese collections, indeed, became highly regarded beyond national borders due to the rarity of their specimens. ${ }^{19}$ Furthermore, the importance of science education was praised by diverse authors. ${ }^{20}$ Consequently, in the following years, various institutions focused on science teaching. The first fully dedicated and specialized natural-history establishment, designed to contribute to the education of the princes - the Royal Botanical Gardens and Natural History Museum of Ajuda, in Lisbon - was built in $1768 ;^{21}$ the University of Coimbra organized, in 1772, a course in natural philosophy, where natural history, experimental physics and chemistry were taught, and for which natural-history and experimental physics cabinets, as well as a botanical garden and a chemistry laboratory, were established;22 and in 1778 the Royal Academy of Sciences was founded, one of its purposes being to boost education in

16 A broad view of the history of Portugal can be found in Anthony R. Disney, A History of Portugal and the Portuguese Empire, Cambridge: Cambridge University Press, 2009; Rui Ramos, Bernado V. Sousa and Nuno G. Monteiro, História de Portugal, Lisbon: Esfera dos Livros, 2009.

17 Robert Fox and George Weisz, The Organization of Science and Technology in France 1808-1914, Cambridge and Paris: Cambridge University Press and Editions de la maison des sciences de l'homme, 1980, p. 1.

18 On museological practices in eighteenth-century Portugal see João Brigola, Colecções, gabinetes e museus em Portugal no século XVIII, Lisbon: Fundação Calouste Gulbenkian e Fundação para a Ciência e Tecnologia, 2003. On natural history in particular see Rómulo de Carvalho, A História Natural em Portugal no século XVIII, Lisbon: Instituto de Cultura e Língua Portuguesa, Ministério da Educação, 1987.

19 Many specimens came from exotic colonized places. Dezallier d'Argenville (1680-1765), for example, referred to specimens from the King João V (1689-1759) collection in his work. Désallier Argenville, La Conchyliologie, ou Histoire naturelle des coquilles de mer, d'eau douce, terrestres et fossiles, avec un traité de la zoomorphose, ou représentation des animaux qui les habitent, Paris: Chez Guillaume de Bure fils, 1780, pp. 555-556. For the foreign interest in Portuguese collections see Brigola, op. cit. (18), pp. 73-82.

20 For example Jacob de Castro Sarmento (1691-1762) or Luís António Verney (1713-1792).

21 In the following years the Natural History Museum of Ajuda became devoted to naturalistic investigations. Its collection grew mostly as a result of the 'philosophical voyages' to the Portuguese overseas territories, but also due to the shipments of different individuals. On its history see Brigola, op. cit. (18), pp. 98-138, 231-361.

22 Founded in Lisbon in 1290 under the designation Studium Generale (Estudo Geral), the university went through a number of relocations until it was moved permanently to its current location, in Coimbra, in 1537. A major reform according to the plans of Marquis de Pombal (1699-1782) occurred in 1772, creating six faculties: theology, canon law, civil law, medicine, mathematics and philosophy. The University of Coimbra remained largely unchanged until the twentieth century, remaining the one and only university in Portugal until 1911. For the natural sciences in the 1770s university reform see A.M. Amorim da Costa, 'As ciências naturais na reforma pombalina da universidade: "estudo de rapazes, não ostentação de príncipes”, in Ana 
order to promote scientific and technical progress, creating a school with natural-history and physics cabinets and chemistry laboratories to educate young people. ${ }^{23}$ As in other European countries the academy broadened the concept of the 'cabinet': such collections should no longer be restricted to elites in private collections or in universities.

As far as secondary education is concerned, before the 1800s, science teaching was not on the agenda. Moreover, the expulsion of the Jesuits from Portugal in the eighteenth century left the country with no feasible network of secondary schools, except a few isolated Latin grammar, Greek, rhetoric and philosophy classes, which were intended to prepare both the aristocracy and the bourgeoisie for higher education. ${ }^{24}$

The University of Coimbra had a particularly active role in the introduction of science in the secondary-school curricula. Worldwide, there are several examples of the interrelationship between universities and secondary schools in different contexts. ${ }^{25}$ In Portugal, Passos Manuel based his policy for secondary education upon the plans prepared by the vice rector of the University of Coimbra, Jose Alexandre de Campos (1794-1850). Alexandre de Campos considered that students who currently pursued higher studies in science had not been sufficiently prepared. ${ }^{26}$ Therefore it was necessary to teach science, with a practical and useful character, to students before they enrolled at university.

Overall, Passos Manuel's new policies for education were the result of pedagogical movements from Europe and revolutionary France, as well as from internal dynamics that had been consolidating and reforming education in Portugal for more than a century. As the University of Coimbra vice rector put it, the 1836 reform was 'a complete system of Public Instruction; eminently Liberal; accommodated to the circumstances,

Cristina Araújo (ed.), O Marquês de Pombal e a Universidade, Coimbra: Imprensa da Universidade de Coimbra, 2014, pp. 179-208.

23 Rómulo de Carvalho, A actividade pedagógica na Academia das Ciências de Lisboa nos séculos XVIII e XIX, Lisbon: Publicações do II centenário da Academia das Ciências de Lisboa, 1981, pp. 14, 18-20; Henrique Coutinho Gouveia, A evolução dos museus nacionais portugueses: tentativa de caracterização, Rio de Janeiro: Seminário Museus Nacionais - Perfil e Perspectivas, 1988, p. 4.

24 Before the expulsion in 1759 the Society of Jesus was in charge of thirty-seven colleges in the Portuguese Empire (sixteen colleges in Portugal, one in Madeira, three in the Azores, twelve in Brazil, one in Angola, three in India and one in Macao). The Jesuits were responsible for the education of about twenty thousand preuniversity students in Portugal. Pombal's secondary-education system led to a massive decrease in the number of students. The number of twenty thousand pre-university students was only reached again in Portugal in the 1930s. Moreover, Pombal's secondary-education system was based on isolated classes rather then on an organized cursus as Jesuit colleges were. Henrique Leitão and Francisco Malta Romeiras, 'The role of science in the history of Portuguese anti-Jesuitism', Journal of Jesuit Studies (2015) 2, pp. 77-99. See also António Alberto Banha de Andrade, A Reforma Pombalina dos Estudos Secundários (1759-1771), Coimbra: Universidade de Coimbra, 1981.

25 See, for example, Kathryn M. Olesko, Physics as a Calling: Discipline and Practice in the Königsberg Seminar for Phisics, Ithaca, NY: Cornell University Press, 1991, pp. 317-365; Ivor F. Goodson, 'Becoming a school subject', in Goodson, Subject Knowledge: Readings for the Study of School Subjects, London: Routledge, 1998, pp. 20-37; Rudolf Stichweh, 'La structuration des disciplines dans les universités allemandes au XIX e siècle', Histoire de l'éducation (1994) 62, pp. 55-73; Sally Gregory Kohlstedt, 'Nature, not books: scientists and the origins of the nature-study movement in the 1890', Isis (2005) 96, pp. 324-352.

26 Deputy José Alexandre de Campos discourse in the parliament (Câmara dos Senhores Deputados), on 12 May 1843, Diário da Câmara dos Senhores Deputados, pp. 178-187, at http://debates.parlamento.pt. 
habits and character of [the Portuguese] people, but at the level and in harmony with the more advanced European systems'. ${ }^{27}$

\section{The historical-naturalistic character of classes: the observational methods}

The first decrees (1836-1894)

The 1836 decree on education clearly pointed out in its preamble the need for and the importance of science teaching in secondary schools: 'there can be no general and fruitful enlightenment if the broad masses of citizens, who do not aspire to higher education, do not possess scientific and technical knowledge indispensable to life in present-day societies'. ${ }^{28}$ Scientific culture was thus fundamental to all citizens of modern nations. It should not be limited to those who intended to pursue university studies. The country's development depended on the practical nature of secondary education. In fact, classical subjects, like Greek and Latin, were considered 'branches of sterile erudition, almost useless for the cultivation of sciences, and without any element that [could] improve the Arts, and lead to the progress of the country's material civilization'. ${ }^{29}$ This statement, included as a preamble to the 1836 educational law, is paradigmatic of the debate opposing science and the humanities which was strident during the nineteenth century, and even the twentieth. ${ }^{30}$ The economic significance of science - that is to say its importance and role in educating the elites to build the society that the bourgeoisie needed - was much valued by Passos Manuel. Scientific knowledge should, therefore, be provided to all citizens in a utilitarian perspective.

Notwithstanding the importance given to science teaching, educational laws did not depict in detail the way science subjects should be taught, referring to regulations that should be prepared by the teachers of each secondary school. ${ }^{31}$ For instance, in 1836, the so-called Passos Manuel Reform only stated that, to teach 'Principles of Physics, Chemistry and Mechanics applied to the Arts and Crafts' and 'Principles of Natural History from the three kingdoms of Nature applied to the Arts and Crafts', each school ought to possess an experimental garden to learn botany, a laboratory to practise chemistry, and a cabinet for the study of physics, zoology and mineralogy. ${ }^{32}$

In the following years, educational laws did not clarify how these cabinets ought to be developed and used. The 1860 decree dictated, simply, that in the secondary schools a small museum of natural history [sh]ould be formed which would satisfy the needs of

27 Deputy José Alexandre de Campos discourse in the parliament (Câmara dos Senhores Deputados), on 11 May 1843, Diário da Câmara dos Senhores Deputados, pp. 168-173, at http://debates.parlamento.pt.

28 Decreto de 17 de Novembro de 1836, Diário do Governo n. ${ }^{\circ}$ 275/1836.

29 Decreto de 17 de Novembro de 1836, Diário do Governo n. ${ }^{\circ}$ 275/1836.

30 Simon, Bertomeu-Sánchez and García-Belmar, op. cit. (9), p. 168. On this issue see also James F. Donnelly, "The "humanist" critique of the place of science in the curriculum in the nineteenth century, and its continuing legacy', History of Education (2002) 31, pp. 535-555.

31 Arts. 53, 63 and 64, Decreto de 17 de Novembro de 1836, Diário do Governo n. ${ }^{\circ}$ 275/1836.

32 Art. 68, Decreto de 17 de Novembro de 1836, Diário do Governo n. ${ }^{\circ}$ 275/1836. This is the only decree that refers to an experimental garden. 
education', ${ }^{33}$ and thirteen years later a rudimentary explanation determined that these museums ought to be composed of collections relevant to zoology, botany and mineralogy, which were 'indispensable for teaching'. ${ }^{34}$ In line with previous laws, in 1880, a specific budget was assigned to fulfill schools' needs for instruments and materials for practical teaching. ${ }^{35}$

Methodological recommendations were no less straightforward. For instance, in 1856 , it was, merely, stated that theoretical explanations had to be followed by observation of specimens, ${ }^{36}$ and in 1880 the analysis of representative specimens of the main orders of animals was advocated. ${ }^{37}$ Accordingly, in 1886, in the final exams, in the fourth year of studies, students' capacity to describe and classify a natural-history specimen was particularly scrutinized. ${ }^{38}$ Taxonomy and biological classification, therefore, occupied key positions in the official educational programmes. Learning to classify was one of the main objectives of the course on natural history.

Once the approach used in science courses was based on the biological classification of specimens, hands-on collections, observation and examination of specimens in zoology, botany, geology and mineralogy were crucial. Classes were, therefore, completely dependent on the didactic material that the school possessed, which would create the necessary conditions for the inductive learning processes that science demanded. Starting with the simple and concrete, and continuing by inference, students would be able to understand the complex and the abstract, truly comprehending the phenomena. The government played an important role in the establishment of the first collections. Zoological specimens, herbaria, rocks and minerals were bought from diverse foreign dealers and distributed to schools. ${ }^{39}$

In short, the idea of teaching collections seemed rooted in the concept of natural-history teaching. Educational programmes encouraged the observation of specimens to be described. Teaching natural history presupposed, hence, the existence of a museum and collections, which were bought and sent to diverse secondary schools. However, in the

33 Art. 82, Decreto de 10 de Abril de 1860, Diário de Lisboa n..$^{\circ}$ 133/1860.

34 Art. 84, Decreto de 31 de Março de 1873, Diário do Governo n. ${ }^{\circ} 77 / 1873$.

35 Carta de Lei de 14 de Junho de 1880, Diário do Governo n. ${ }^{\circ}$ 138/1880.

36 Edital (s.d.), Diário do Governo n. ${ }^{\circ} 122 / 1856$.

37 Portaria (s.d.), Diário do Governo n. $.^{\circ} 241 / 1880$.

38 Art. 42, Decreto de 12 de Agosto de 1886, Diário do Governo n. ${ }^{\circ}$ 195/1886.

39 Arquivo Nacional da Torre do Tombo (hereafter ANTT), Consulta do Conselho Superior de Instrução Pública (CSIP) sobre a criação da cadeira de 'Princípios de física e química, e introdução à história natural' no Liceu de Ponta Delgada, com data de 5 de Dezembro de 1854 (MR, M 3502); ANTT, Consulta do CSIP sobre o meio de comprar utensílios para a cadeira de 'Princípios de física e química, e introdução à história natural' no Liceu de Ponta Delgada, com data de 19 de Junho de 1855 (MR, M 3502); ANTT, Nota do CSIP com a relação dos utensílios necessários para a de cadeira princípios de física e química, e introdução à história natural no Liceu de Ponta Delgada, com data de 2 de Outubro de 1855 (MR, M 3502); Carlos Beato, 'Os liceus e as ciências (1836-1860): Um estudo sobre o processo de criação das disciplinas de ciências físicas e naturais nos liceus portugueses', PhD thesis, Instituto de Educação, Universidade de Lisboa, 2011, p. 392; Inês Gomes, 'Os Museus Escolares de História Natural: Análise Histórica e Perspectivas de Futuro (1836-1975)', PhD thesis, Faculdade de Ciências, Lisbon, 2014, pp. 126-129; Inês Gomes, 'The scientific heritage of Portuguese secondary schools: a historical approach', Paedagogica Historica (2017), at https://doi.org/10.1080/00309230.2017.1409771. 
first laws issued, allusions to inductive methodologies and cabinets were invariably brief and generic. Robert Kohler notes that 'the generic laboratory of the nineteenth and twentieth centuries is a quasi-natural feature of the world of science ... too familiar to need explication, analytically invisible'. ${ }^{40}$ The situation appears to be similar for teaching collections. In Portugal, likewise, legislation was not very explicit, although these teaching aids were considered indispensable. School museums of natural history have in fact appeared in legislation as evidence, requiring no further explanation about their constitution, development and use. The aims assigned to collections would only be clarified in 1894-1895.

\section{4-1895 and the Jaime Moniz reform}

The development of a national network of secondary schools was not a smooth journey: between 1836 and 1894 nine reforms were issued. The 1836 law was considered by its opponents an 'ambitious project, considering the nation's strength and needs', which was infeasible given that Portugal was a small, poor and backward country. ${ }^{41}$ In the 1870s and 1880s, critics targeted, among other aspects, the 'unity' of school subjects, or, in other words, the organization of subjects and the relations between them. ${ }^{42}$ Secondary schools housed diverse disciplines that were not interrelated. ${ }^{43}$

Jaime Moniz proposed, in 1894, another educational reform aspiring, precisely, to solve this problem. Moniz was invited by Minister João Franco to chair the committee to draft an educational reform proposal. He had been director of the Curso superior de letras (a course the aim of which was, among others, to prepare secondary-school teachers), general director of public instruction, and vice president of the Superior Council of Public Instruction. ${ }^{44}$ Moniz made a detailed comparative study of the secondary-school curricula of several countries, paying particular attention to the German school system. ${ }^{45}$ Historians have described this reform as 'the most important fact' in

40 Robert E. Kohler, 'Lab history: reflections', Isis (2008) 99, pp. 761-768, 762.

41 ANTT, Minuta da consulta, Relatório, e Projectos de Reforma da Instrução Primária e Secundária, com data de 3 de Dezembro de 1838 (MR, M 3499). On the difficulties of implementing the 1836 decree see also, for example, ANTT, Esclarecimentos do Conselho Geral Director do Ensino Primário e Secundário aos quesitos apresentados pelo deputado Roque Joaquim Fernandez Thomaz nas Cortes, com data de 16 e Fevereiro de 1838 (MR, M 2127).

42 Jorge Ramos do Ó, O governo de si mesmo: modernidade pedagógica e encenações disciplinares do aluno liceal (último quartel do século XIX - meados do século XX), Lisbon: Educa, 2003, pp. 208-224.

43 João Barroso, 'A influência do regime de classes na organização pedagógica e na administração do Liceu', in Rogério Fernandes and Justino Magalhães (eds.), Para a história do ensino liceal em Portugal: Actas dos colóquios do $I^{\circ}$ Centenário da reforma de Jaime Moniz, Braga: Sociedade Portuguesa de Ciências da Educação/Centro de Estudos em Educação e Psicologia, 1999, pp. 16-36, 18.

44 See Maria Cândida Proença, A Reforma de Jaime Moniz: Antecedentes e Destino Histórico, Lisbon: Edições Colibri, 1997, pp. 173-244, 363-369.

45 Studies done by Jaime Moniz, prior to the preparation of the reform of 1894-1895, were published in 1919 by the State Department of Public Instruction, allowing us to understand in depth the pedagogical thinking of the author. Jaime Moniz, Estudos de ensino Secundário, Lisbon: Imprensa Nacional, 1919. In Germany the aims of secondary education were not simply to prepare students for higher education. Its objectives were much broader and in that context the teaching of the different disciplines was valued not only for the knowledge and skills that were taught but for the mental faculties that the various disciplines, as a whole, allowed to develop. This led Moniz to defend so vehemently the regime of classes as opposed to 
the history of Portuguese liceus, ${ }^{46}$ when many of the features that are today considered part of secondary education were established in the final years of the nineteenth century: ${ }^{47}$

pupils grouped in graduated classes of more or less homogeneous composition; teachers working individually, assuming a profile of generalists (primary education) or specialists of a subject (secondary education); specific spaces for school work, organized from a pedagogy centered essentially on the classroom; rigid school schedules, which define a social control of time, assigning one hour to each lesson (with small variations). ${ }^{48}$

Other changes included matters such as the use of textbooks, exams and pupils' duties. ${ }^{49}$ Did this reform also change the teaching of science and, in particular, the teaching of natural history?

As far as natural history is concerned, its importance should be assessed in the broader context of the objectives that had been assigned to secondary schools. Secondary education intended to gradually develop students' minds 'by a methodical and progressive acquisition of knowledge', enabling them to continue their studies in universities. According to university professors, students 'fainted in the face of the most rudimentary analytical work'; they didn't know how to observe, classify or infer. ${ }^{50}$

In this context, Jaime Moniz praised the inductive method for the development of intellectual faculties. Moreover, he argued that teaching natural history was crucial in order for a student to become a citizen. Intuition, observation, experiment, generalization and inference abilities were skills that could best be developed in natural-history classes, 'without which a man [could] hardly be considered a citizen of modern times' ${ }^{51}$ Scientific knowledge was considered the only form of true knowledge.

The growing importance attributed to natural-history subjects within Moniz's reform thus became anchored in notions of mental discipline, and not so much in the knowledge per se that students would acquire. This aspect was probably the reason why a new terminology was used. Natural history would from then on be called natural sciences as a way to emphasize this new broad dimension. ${ }^{52}$ In practice, however, the situation had

the regime by disciplines that prevailed in Portugal, making the system of Portuguese secondary education particularly disorganized. Ramos do Ó, op. cit. (42), pp. 228-229.

46 Vasco Pulido Valente, O Estado liberal e o ensino: Os liceus portugueses (1834-1930), Lisbon: Gabinete de Investigações Sociais, 1973, p. 64.

47 António Nóvoa, João Barroso and Jorge Ramos do Ó, 'O todo poderoso Império do Meio', in António Nóvoa and Ana Teresa Santa-Clara (eds.), 'Liceus de Portugal': Histórias, Arquivos, Memórias, Porto: Asa, 2003, pp. 17-73, 36-37; Jorge Ramos do Ó, Ensino liceal (1836-1975), Lisbon: Secretaria-geral do Ministério da Educação, 2009, pp. 8-9, 43; and Bento Cavadas, 'A evolução dos manuais escolares de Ciências Naturais do ensino secundário em Portugal 1836-2005', PhD thesis, Facultad de Educación, Universidad de Salamanca, 2008, p. 257. On this reform see Proença, op. cit. (44); and Ramos do Ó, op. cit. (42), pp. 224-275.

48 Nóvoa, Barroso and Ramos do Ó, op. cit. (47), p. 37.

49 Ramos do Ó, op. cit. (42), pp. 230, 252-260.

50 Decreto de 22 de Dezembro de 1894, Diário do Governo n..$^{\circ}$ 292/1894.

51 Decreto de 14 de Setembro de 1895, Diário do Governo n. ${ }^{\circ}$ 208/1895.

52 In this regard see Dorothy B. Rosenthal and Rodger W. Bybee, 'Emergence of the biology curriculum: a science of life or a science of living', in Thomas S. Popkewitz (ed.), The Formation of the School Subjects: The Struggle for Creating an American Institution, New York: The Falmer Press, 1987, pp. 123-144, 132. In 1926 and 1927, syllabi used terms such as 'biological sciences' and 'geological sciences' rather than 'natural sciences'. 
changed little. The teaching of botany, zoology, geology and mineralogy did not change, maintaining the division into different scientific branches and emphasizing specimens' structural details.

Collections were also essential to achieve the objectives assigned to science teaching. Syllabi celebrated the examination of specimens. Real learning required students to reason things through observation. 'Students should observe, describe and compare, learning, like this, the most important notions of morphology and systematics'. ${ }^{53}$ As Jaime Moniz stated supporting the use of collections, 'learning natural sciences only by textbooks, ha[d] little or no utility at all'. ${ }^{54}$ And he persuaded teachers to always use collections in their classes:

To study natural history direct observation of specimens or objects is the ideal method. The study should be based on the examination of live or prepared specimens ... on the examination of live plants and, in their absence, on the examination of herbaria, drawings, models, etc. ${ }^{55}$

Thus Jaime Moniz made explicit the nature and role of teaching collections, unlike previous reforms, which, as previously stated, presumed that the terms 'museum' and 'collection' were self-explanatory.

In line with the educational laws, the government, taking into account the 'urgent need' to organize collections for the teaching of zoology, determined that the University of Coimbra should arrange such collections. ${ }^{56}$ Approximately seventy specimens (birds, reptiles, amphibians, fish, brachiopods, cephalopods, gastropods, lamellibranchs, hymenoptera, coleoptera, lepidoptera, diptera, hemiptera, orthoptera, myriapods, arachnids, crustaceans, worms, echinoderms and coelenterates) were then sent to a few secondary schools. ${ }^{57}$

\section{Collections in the twentieth century}

The impact of Jaime Moniz's reform was enormous. Contemporaries considered it a moment of 'great educational progress' that allowed Portugal to approach the 'most culturally advanced nations' ${ }^{58}$ During the next two decades, new legislation copied (with small changes) the 1894 reform. For instance, Alicia Pestana, a Portuguese pedagogue from the Spanish Institución Libre de Enseñanza, noted that the educational programmes in force in 1914-1915 'were substantially the same as those in the last years of the monarchical era' ${ }^{59}$

For the use of different terminologies in science teaching see also Ivor Goodson, 'História de uma Disciplina Escolar: As Ciências', in Goodson, A Construção Social do Currículo, Lisbon: Educa, 1997, pp. 53-78, 66.

53 Decreto de 14 de Setembro de 1895, Diário do Governo n. ${ }^{\circ}$ 208/1895.

54 Decreto de 14 de Setembro de 1895, Diário do Governo n. ${ }^{\circ}$ 208/1895.

55 Decreto de 14 de Setembro de 1895, Diário do Governo n. ${ }^{\circ}$ 208/1895.

56 Arquivo da Universidade de Coimbra, Processo do Professor Paulino de Oliveira - Carta enviada pela DGIP ao director do Museu de Coimbra, Manuel Paulino d'Oliveira, a 11 de Março de 1896.

57 ANTT, Correspondência entre a Universidade de Coimbra e a DGIP ao longo de 1898 (MR M 3806 (processo 12 e 73); M 3809 (processo 393); M 3810 (processo 778)); Gomes, 'The scientific heritage of Portuguese secondary schools', op. cit. (39), pp. 144-146.

58 Decreto de 29 de Agosto de 1905, Diário do Governo n. ${ }^{\circ}$ 194/1905.

59 Alicia Pestana, La educación en Portugal, Madrid: Junta para Amparo de Estudios y Investigaciones Científicas, 1915 , p. 73. 
The importance of science teaching, however, was reinforced. In 1905, for example, the number of hours per week assigned to science teaching increased, ${ }^{60}$ and in the last years of studies, physical and natural sciences were, for the first time, taught as distinct subjects. ${ }^{61}$ Thursday afternoons were devoted to practical science teaching in cabinets, laboratories or the field; ${ }^{62}$ the importance of this type of education was such that teachers were only appointed after passing an examination that tested their skills performing practical exercises in the museum and laboratory. ${ }^{63}$ In natural history, the mental discipline attributed to its study was still a key feature. Natural-science classes did not intend 'to create naturalists, but to develop students' accurate observation habits'. ${ }^{64}$ The 'exact observation of phenomena' presumed museums and collections for practical classes. Educational programmes, in fact, mentioned the study of specimens from the school museum.

This paper only mentions a small proportion of the examples that could be given. Every educational law in Portugal in this period advocated the study of nature based on the observation, comparison and classification of specimens. What is important to emphasize is that observational methods were always crucial in the study of zoology, botany, geology and mineralogy. For instance, museums and collections were not put aside. In 1937, for example, the government published a list that established the material which every school should have in their 'Natural Science Museum' ${ }^{65}$ In 1947, teachers still had to pass an examination in which they had to show familiarity with taxonomy, ${ }^{66}$ and in the 1950s pupils' ability to classify and describe natural-history specimens was also analysed in natural-sciences practical examinations in their last year of studies. ${ }^{67}$ In the late 1960 s specimens were still being purchased. ${ }^{68}$ Teachers continued to emphasize the great value of taxonomy and systematics, ${ }^{69}$ and students were even encouraged to help in increasing collections by collecting and conserving small animals themselves. ${ }^{70}$

Today, Portuguese secondary schools hold important collections, many of them organized in the late nineteenth century and the early twentieth. These collections comprise different groups of animals, mounted or preserved in alcohol, skeletons, zoological and botanical anatomical models, rocks, minerals, fossils, crystallographic and geological models, molluscs' shells, wood samples and herbaria, as well as didactic materials

60 Art. 5, Decreto de 29 de Agosto de 1905, Diário do Governo n. ${ }^{\circ}$ 194/1905.

61 Art. 3, Decreto de 29 de Agosto de 1905, Diário do Governo n. ${ }^{\circ}$ 194/1905.

62 Art. 6, Decreto de 29 de Agosto de 1905, Diário do Governo n. ${ }^{\circ}$ 194/1905. Subsequent reforms even detailed the number of hours per week that should be assigned to practical teaching.

63 Art. 39, Decreto de 29 de Agosto de 1905, Diário do Governo n. ${ }^{\circ}$ 194/1905.

64 Decreto n. ${ }^{3}$, de 3 de Novembro de 1905, Diário do Governo n. ${ }^{\circ}$ 250/1905.

65 Declaração do Ministério da Educação Nacional, Diário do Governo n. ${ }^{\circ}$ 278/1937, I Série.

66 Art. 202, Decreto n. ${ }^{\circ}$ 36:508, de 17 de Setembro de 1947, Diário do Governo n. ${ }^{\circ}$ 216/1947, I Série.

67 Guilherme F. Pimentel, 'A propósito das provas práticas de ciências naturais dos exames do $7 .^{\circ}$ ano', Labor (1953) 132, pp. 632-635.

68 Arquivo da Secretaria Geral do Ministério da Educação, Notas de requisição da Comissão de Reapetrechamento das Escolas Superiores e Secundárias.

69 Maria Joaquina Prates Costa, 'A observação no ensino das ciências naturais do $2 .^{\circ}$ ciclo. Exemplificação com um plano de lição', Palestra (1959-1960) 7, pp. 184-186.

70 'As ciências naturais no campo da investigação, elaboração e montagem de laboratórios', Palestra (19661967) 29, pp. 81-105. 
from more recent times, such as wall charts, slides, films, microscopes and microscopic preparations. Some of this material was manufactured in the nineteenth and the early twentieth centuries by major European manufacturers, such as Emile Deyrolle, Robert Brendel or Louis Auzoux. ${ }^{71}$ The similarities between the Portuguese collections and other collections of diverse European schools are remarkable. Catalogues from Spanish or French schools are paradigmatic of what in Portugal was meant by a natural-history teaching collection in the transition from the nineteenth to the twentieth century. ${ }^{72}$

\section{Laboratory-based teaching: the experimental methods}

The establishment of the First Republic in Portugal, in 1910, renewed expectations of truly reforming education, purging the nation from all the 'evils' which kept Portugal distant from wider European progress. ${ }^{73}$ The fight against illiteracy was one of the great priorities of the republic and consequently the reforms of primary education were the first to be published. Reforming the university was also considered fundamental: in 1911 the Universities of Lisbon and Porto were created in order to end Coimbra's supremacy. ${ }^{74}$

Secondary education was, therefore, left behind. Moreover, political instability kept the 1905 monarchical educational law in force for a long time. In 1914, however, before the establishment of a major reform, the government issued several instructions for teaching' (instruções para o ensino em classe), clarifying the aims of secondary education which were not just acquiring a 'sum and variety' of knowledge, but mainly 'develop[ing] the faculties of the spirit'. ${ }^{75}$ Teachers ought to attract the pupils' attention and seek to develop their sense of initiative.

In this context, major changes in science teaching seem also to have occurred. A new subject regarding the teaching of natural and physical sciences was included in the national curriculum in the same year. ${ }^{76}$ This new course (trabalhos individuais educativos, or individual educational assignments) should be taught in 'laboratories, museums or in the field', and its main objective was a 'scientific education' that sought to create research habits and encourage critical reasoning. ${ }^{77}$ Another innovative aspect resulted from the roles expected of students and teachers. Work should be individual, 'respecting and cultivating ... students' personality and initiative', ${ }^{78}$ and should not be a 'mere execution of recipes' but rather 'research problems that interest the student, and allow him,

71 Gomes, 'Os Museus Escolares de História Natural', op. cit. (39), pp. 53-66; Gomes, 'The scientific heritage of Portuguese secondary schools', op. cit. (39), pp. 144-146.

72 Francis Gires (ed.), L'Empire des sciences ... naturelles: Cabinets d'histoire naturelle des lycées impériaux de Périgueux \& Angoulême, Niort: ASEISTE, 2013, pp. 145-347; José Damián López Martínez (ed.), Las ciencias en la escuela: El material científico y pedagógico de la Escuela Normal de Murcia, Murcia: edit.um, 2012.

73 Carvalho, op. cit. (3), p. 651.

74 Carvalho, op. cit. (3), p. 682.

75 Portaria n. ${ }^{\circ} 230$, de 21 de Setembro de 1914, Diário do Governo n. ${ }^{\circ}$ 171/1914, I Série.

76 Decreto n. ${ }^{\circ}$ 896, de 26 de Setembro de 1914, Diário do Governo n. ${ }^{\circ}$ 175/1914, I Série.

77 Art. 1, Portaria n. ${ }^{\circ} 239$, de 26 de Setembro de 1914, Diário do Governo n. ${ }^{\circ}$ 175/1914, I Série.

78 Art. 2, Portaria n. ${ }^{\circ}$ 239, de 26 de Setembro de 1914, Diário do Governo n. ${ }^{\circ}$ 175/1914, I Série. 
by himself, to discover and rediscover'. ${ }^{79}$ Such learning would require students to reason about things autonomously, carrying out experiments themselves, and teachers would value not only the observation and experiment itself, but also the way students interpreted and reported their procedures and findings. ${ }^{80}$ Teachers' guidance should be minimal. Indeed, teachers should act as 'fellow workers'. ${ }^{81}$

This new subject seems to have been part of a pedagogical movement that, in the early years of the twentieth century, advocated changes in science-teaching methodologies. ${ }^{82}$ As far as the study of nature was concerned, the importance given to taxonomy was the main target of criticism. Science instruction should be based on problems of everyday lives and provide 'citizens with an understanding of the essential nature of scientific thinking. ${ }^{83}$ Students should perform practical experiments and teachers should work, as noted in the Portuguese law, as guides. ${ }^{84}$ Changes in teaching approaches were common at the turn of the twentieth century. In France, for instance, the 1902 educational reform was paradigmatic of these changes: experience and induction would have a prominent place; 'students should be shown how science was done and not a science already done'. ${ }^{85}$ In England and Wales, concern for the construction of laboratories was constant during the twentieth century. ${ }^{86}$ In Spain, although the impact of the reforms carried out in the early years of the twentieth century, and of the pedagogical innovations that they intended to introduce, has not yet been thoroughly studied, pedagogical laws of this period also were intended 'to regenerate Spain through a culture of precision' ${ }^{87}$ In this context, several attempts at pedagogical renewal that aimed to

79 Art. 3, Portaria n. ${ }^{\circ}$ 239, de 26 de Setembro de 1914, Diário do Governo n. ${ }^{\circ}$ 175/1914, I Série.

80 Art. 4, Portaria n..$^{\circ}$ 239, de 26 de Setembro de 1914, Diário do Governo n..$^{\circ}$ 175/1914, I Série.

81 Art. 9, Portaria n..$^{\circ} 239$, de 26 de Setembro de 1914, Diário do Governo n..$^{\circ}$ 175/1914, I Série.

82 Goodson, 'História de uma Disciplina Escolar', op. cit. (52).

83 John L. Rudolph, 'Turning science to account: Chicago and the general science movement in secondary education, 1905-1920', Isis (2005) 96, pp. 353-389, 353. See also Edgar W. Jenkins, 'Science, sentimentalism or social control? The nature study movement in England and Wales, 1899-1914', History of Education: Journal of the History of Education Society (1981) 10, pp. 33-43; José Ramón Bertomeu Sánchez and Josep Simon Castel, 'Viejos objetos y nuevas perspectivas historiográficas: la cultura material de la ciencia en las aulas del siglo XIX', in Leoncio López-Ocón, Santiago Aragón and Mario Pedrazuela (eds.), Aulas con memoria: Ciencia, educación y patrimonio en los institutos históricos de Madrid (1837-1936), Madrid: CEIMES/Doce Calles/Comunidad de Madrid, 2012, pp. 61-63; John Dewey, 'Science as subject matter and as method', Science (1910) 31, pp. 121-127.

84 Pedro Ruiz-Castel, 'Scientific instruments for education in early twentieth-century Spain', Annals of Science (2008) 65, pp. 519-527, 522; Henry Edward Armstrong, The Teaching of Science Method and Other Papers on Education, London: Macmillan, 1903, p. 237, cited in Bertomeu Sánchez and Simon Castel, op. cit. (83), p. 61; Edgar W. Jenkins, 'Some sources for the history of science education in the twentieth century, with particular reference to secondary schools', Studies in Science Education (1980) 7, pp. 27-86, 36-38.

85 Nicole Hulin, 'La conception de l'enseignment de la physique dans la réforme de 1902', in Hulin (ed.), Physique et humanités scientifiques: Autour de la réforme de l'enseignement de 1902. Etudes et documents, Villeneuve d'Ascq: Presses universitaires du Septentrion, 2000, pp. 29-43, 35; Bruno Belhoste, 'L'enseignement secondaire français et les sciences au début du XXe siècle: La réforme de 1902 des plans d'études et des programmes', Revue d'histoire des sciences (1990) 43, pp. 371-400.

86 Jenkins, op. cit. (84), pp. 44-46.

87 Leoncio López-Ocón, 'Introducción: Reflexiones sobre la modernidad en las aulas de bachillerato en el primer tercio del siglo xx', in López-Ocón (ed.), Aulas modernas: Nuevas perspectivas sobre las reformas de la enseñanza secundaria en la época de la JAE (1907-1939), Madrid: Universidad Carlos III, 2014, pp. 9-46, 22. 
develop new teaching methods were put in force in order to encourage practical and experimental teaching in secondary education, allocating funds for the purchase of didactic material for laboratories and cabinets for the teaching of the sciences. ${ }^{88}$

Experimentation, rather than observation, was therefore emphasized. In this context, teaching materials should change. In fact, inventories of school materials reveal that new didactic materials, like microscopes, magnifiers, dissections tools or other laboratory equipment, were brought into the classroom. ${ }^{89}$ But which 'new' teaching practices were in fact performed after the 1914 decree? By 1914 no official content was published. ${ }^{90}$ Nevertheless, practical activities comprised, at the time in question, not only classification of zoological and botanical specimens and analysis of minerals and crystallographic models, but also microscopic examinations and dissections of small animals. Laboratory techniques were thus emerging. But was it a truly laboratory-based science teaching grounded in experimentation and inquiry?

In 1929, three years after the establishment of the dictatorial regime in Portugal, when, finally, practical science teaching was officially regulated, in line with schools' practices, hands-on analysis of specimens in zoology, botany, geology and mineralogy was still a central methodology, as was the organization of collections by students. ${ }^{91}$ The use of the microscope was also fundamental, as well as simple physiology experiments or dissection of plants, invertebrates or small vertebrates. The doctrine of mental discipline, linked with laboratory work, was very clearly stated. The laboratory allowed students to develop not only the mind but also the body and character: acquiring direct observation skills, working methods, prudential habits and mental integrity, habits of cleanliness and mental ability. ${ }^{92}$ Although educational programmes included topics such as heredity, ecology and physiology, subjects that went beyond the boundaries of traditional natural history, observation and description were still the methods that were encouraged, notwithstanding the fact that observations were preferably made with the use of microscopes. Inquiry and experimentation were still not predominant in Portuguese secondary schools. In accordance, terms like 'natural-history studies' were frequently used in the 1929 law. Additionally, teaching practices were strictly defined. Experimentation and autonomy, advocated in 1914, appear to have been forgotten. Students 'follow[ed] recipes', despite the 1914 decree asserting the contrary.

88 López-Ocón, op. cit. (87); Leoncio López-Ocón, 'La importancia de una circular de 1906 para el equipamiento científico de los institutos', in Actas de las VIII Jornadas de la Asociación nacional para la defensa del patrimonio de los institutos históricos. Badajoz 2-4 mayo 2014, at https://drive.google.com/file/d/ 0B34YLF1irl09S0dsLWVuWINNNjA/edit, accessed 10 October 2017.

89 Arquivo da Secretaria-geral do Ministério da Educação, Inventários enviados pelos liceus à Direcção Geral do Ensino Secundário em resposta a circular de 4 de Agosto de 1928, DGEL Série 23; Cx. 1751 (Livro 11, n. $\left.{ }^{\circ} 918\right)$.

90 Universities should provide their museums and laboratories for secondary-education teachers wishing to improve their technical knowledge to better carry out their new duties: Art. 6, Portaria n. ${ }^{\circ} 239$, de 26 de Setembro de 1914, Diário do Governo n. ${ }^{\circ}$ 175/1914, I Série.

91 Decreto n. ${ }^{\circ} 16: 362$, de 14 de Janeiro de 1929, Diário do Governo n. ${ }^{\circ}$ 11/1929, I Série.

92 Decreto n. ${ }^{\circ}$ 16:362, de 14 de Janeiro de 1929, Diário do Governo n. ${ }^{\circ}$ 11/1929, I Série. 


\section{Observation versus experimentation}

To sum up, educational laws have always advocated observation as a crucial approach to the study of nature. Although, in the second decade of the twentieth century, laboratory techniques like dissection and microscopy became important, they did not actually change the natural-historical character of science classes. While the history of science teaching in Portuguese secondary schools, particularly concerning everyday practices, has not yet been intensively scrutinized, the few studies that do exist point to a predominance of historical-naturalistic approaches, not only in the nineteenth century, but also throughout the twentieth. ${ }^{93}$ Observation and description rather than experimentation remained central, and study of collections has never been replaced by laboratory procedures. The approaches coexisted. This poses a question: why has natural-history teaching changed so little in Portugal despite attempts to reform it?

A possible reason relates to the fact that although policies kept changing, institutions remained the same. For instance, similarities between teaching institutions from different regimes which apparently were based on distinct ideological principles are not uncommon. In France, for example, Fox and Weisz point out that the higher-education system, between 1806 and 1811, generally respected the structure inherited from the Ancien Régime. ${ }^{94}$ A similar state of affairs can be found at the Lisbon Polytechnic School, created in 1837. Professors assigned to teach their disciplines came from the Royal Naval Academy, thus not breaking the educational model implemented in the higher technical schools before the Liberal Revolution. ${ }^{95}$ As far as secondary education was concerned, teachers also remained the same through regime changes. Actually, transformations that took place between the sixteenth and eighteenth centuries in colleges dependent on religious congregations would shape what is usually called 'the modern secondary school' in accordance with the precepts of Jaime Moniz. ${ }^{96}$ Moreover, in 1839, the government ordered that teachers from the Real Colégio dos Nobres (the most emblematic of all schools created by the Pombaline educational reform) and other religious colleges - which had ceased after the Portuguese Civil War - should be distributed to different schools in order to 'reduce the chaos' in secondary education. ${ }^{97}$ Their influence in the construction of the 'liberal school', therefore, would have been considerable. This is a subject that would be worth exploring in order to assess everyday teaching practices. In sum, policies changed but teachers remained, as well as teaching practices. There was, in fact, great inertia in science education in Portugal. In 2007 the Portuguese government developed a modernization programme for secondary schools. Among other aspects, the school laboratory was

93 Gomes, opera cit. (39); Catarina Leal, 'Na Sombra da História Natural: O Ensino Liceal das Ciências Biológicas e Geológicas (1895-1954)', MSc thesis, Universidade de Lisboa, 2007; Teresa Salomé Mota, 'História do ensino da geologia em Portugal: análise dos manuais do ensino liceal no Estado Novo (19471974)', MSc thesis, Universidade do Minho, Braga, 2001.

94 Fox and Weisz, op. cit. (17), p. 1.

95 Carolino, op. cit. (12), p. 409.

96 Ramos do Ó, op. cit. (42), pp. 165-173.

97 ANTT, Consulta do Conselho Geral Director do Ensino Primário e Secundário, com data de 10 de Julho de 1840 (MR, M 3499). 
remodelled, with the aim of breaking with the dichotomy between theoretical classes, given in a traditional classroom, and practical classes, given in a laboratory environment. This would increase inquiry-based science teaching. ${ }^{98}$ In reality, although general conditions were in fact improved (such as location, ventilation and air temperature, technology, acoustics, safety conditions, aesthetics, lighting, typology of spaces, number of labs, specific equipment and furniture), there were no changes in teaching practices. ${ }^{99}$ Reasons for the maintenance of teaching practices are, once again, not totally clear. As Fernandes puts it, this was the combined result of an old habit, of the high number of pupils limiting the use of labs for all science lessons, but also of a lack of communication of the assumptions of the new model: ${ }^{100}$ the 'rebuilding project ... was not part of an integrated approach to school science reform, intervening on policy, organisational, curriculum, assessment, professional development and other domains usually included in educational change models' ${ }^{101}$ This lack of coordination seems typical of the execution of Portuguese educational laws over time.

A second plausible explanation regards the educational programmes, where changes seem to have been smooth over the years. In particular, the emergence of a generic biological curriculum (usually linked with laboratory-based teaching approaches) was gradual and never replaced a traditional approach centred on biological classification (and thus linked with natural-historical approaches). For example, in 1856, besides taxonomy, the study of useful and harmful plants and animals, including agricultural and industrial plants and domestic animals with economic value, was included in the natural-history programme. ${ }^{102}$ By 1895 , programmes emphasized also general hygiene notions regarding the importance of sleep, food or exercise. ${ }^{103}$ These would become recurring topics in subsequent reforms. Other subject matters, such as physiology, heredity, selection, evolution, adaptation or ecology, have emerged gradually in secondaryschool curricula throughout the years. These themes reveal the emergence of a curriculum that valued natural sciences as an area of knowledge that went beyond the limits of the so-called natural history, such as highly specialized courses. However, traditional natural history was not erased from Portuguese secondary schools, surviving within the diverse syllabi issued by various governments.

Finally, political instability and financial problems have been recurrent excuses to justify the lack of suitable conditions for applying the law, which could have led to the change of teaching practices. ${ }^{104}$ In fact, between 1836 and 1910, eleven reforms were issued, and during the First Republic there were more than forty ministers of public instruction (ministros da instrução pública), which made it difficult to carry out

98 João Fernandes, 'Analysing activities in the Portuguese secondary schools' Science Learning Studios', PhD thesis, Almada, FCT-UNL, 2017, pp. 27-64.

99 Fernandes, op. cit. (98), pp. 227-284, esp. 281-282.

100 Fernandes, op. cit. (98), p. 284.

101 Fernandes, op. cit. (98), p. 282.

102 Edital (s.d.), Diário do Governo n. ${ }^{\circ} 122 / 1856$.

103 Decreto de 14 de Setembro de 1895, Diário do Governo n..$^{\circ}$ 208/1895.

104 See, for instance, António Candeias, 'Primeira República Portuguesa (1910-1926): educação, ruptura e continuidade, um balanço crítico', in Ernesto Candeias Martins (ed.), Actas do V Encontro Ibérico de História da Educação: Renovação Pedagógica, Coimbra: Alma Azul, 2005, pp. 161-192. 
any project. Other obstacles to laboratory-based science teaching also arose. For instance, teachers expressed difficulties in accomplishing educational programmes due, for example, to their extension; to the reduced number of practical classes, which in addition were of short duration; or to the high number of pupils per class, ${ }^{105}$ which did not allow them 'to give an individualized character to lessons nor to create the scientific spirit advocated'. ${ }^{106}$ Furthermore, lack of material, which could have led to the use of older didactic materials for long periods, was also advocated as a main reason for inappropriate science classes. ${ }^{107}$ In fact, in Portugal there are various examples of 'unusually long cycles of use', which have led to the existence today of an outstanding scientific heritage, fortunately preserved by museums. For instance, an eighteenth-century chemistry laboratory at the University of Coimbra (1772), a nineteenth-century chemistry laboratory at the University of Lisbon (1857) and an early twentieth-century chemistry laboratory at the University of Porto (1912) were not replaced after a couple of decades of use in response to new teaching and research needs, as they usually are. Despite requests for new infrastructure in the twentieth century, the three laboratories remained in use, with some architectural adaptations. ${ }^{108}$ Other 'time capsules', as Lourenço and Dias call them, ${ }^{109}$ exist in Portugal, namely, as mentioned earlier in this paper, in secondary schools where nineteenth- and early twentieth-century scientific collections and original laboratories are still preserved.

\section{Concluding remarks}

Zoology, botany, geology and mineralogy were taught in Portuguese secondary schools from the mid-nineteenth century. Traditional natural history retained its place on the curricula, withstanding political and pedagogical changes of the nineteenth and twentieth centuries. On the one hand, international pedagogical changes did not lead to significant disruptions and have, rather, been gradually integrated into the curriculum. On the other hand, governments across the whole political spectrum have continued to enforce teaching methods that used specimens and collections for engaging students in practical exercises. Although, in 1914, a different approach seems to have emerged, giving particular emphasis to scientific inquiry, and consequently changing classroom material culture, observation and description remained central in natural-science classes instead of experimentation. Accordingly, specimens and collections have always, even during the twentieth century, played an important role inside the classroom. Taking into account the fact that the documentary and archival heritage of secondary schools is often not organized or accessible, this study of the development of science instruction

105 Leal, op. cit. (93), p. 81.

106 Arquivo Histórico do Colégio Militar, Relatório do director da sexta classe relativo ao ano lectivo de 1925-1926; Relatório sobre o funcionamento das aulas de ciências naturais da sexta classe de ciências, pelo professor Botelho de Medeiros, relativo ao ano lectivo de 1931-1932.

107 Leal, op. cit. (93), pp. 80-84.

108 Marta C. Lourenço and José Pedro Sousa Dias, “Time capsules” of science: museums, collections, and scientific heritage in Portugal', Isis (2017) 108, pp. 390-398, 395-397.

109 Lourenço and Dias, op. cit. (108). 
in Portuguese secondary schools offers an account of the origin and development of Portuguese natural-history instruction in secondary schools and its interplay with material-culture collections, pointing to great stability in science teaching for over a hundred years. Future research on science education in Portugal should be supported in order to acknowledge the historical importance of scientific collections in the everyday teaching of science and to understand the reasons behind the stability of Portuguese naturalhistory classes in its full complexity. 